\title{
The Causative Agents, Their Antimicrobial Susceptibilities and Their Effects on Mortality of Intensive Care Infections in Atatürk University Medical Faculty Research Hospital
}

\author{
Atatürk Üniversitesi Tıp Fakültesi Araştırma Hastanesindeki Yoğun Bakım Enfeksiyonlarının \\ Etkenleri, Antimikrobiyal Duyarlııkları ve Mortalite Üzerine Etkileri
}

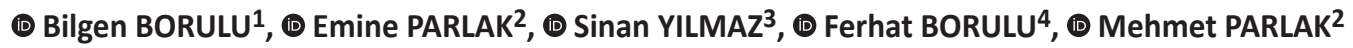 \\ 1University of Health Sciences Turkey, Erzurum Regional Training and Research Hospital, Clinic of Infectious Diseases and Clinical Microbiology, \\ Erzurum, Turkey \\ 2Atatürk University Faculty of Medicine, Department of Infectious Diseases and Clinical Microbiology, Erzurum, Turkey \\ ${ }^{3}$ Atatürk University Faculty of Medicine, Department of Public Health, Erzurum, Turkey \\ ${ }^{4}$ Atatürk University Faculty of Medicine, Department of Cardiovascular Surgery, Erzurum, Turkey
}

\section{Abstract}

Introduction: Hospital-acquired infections (HAls) are one of the important mortality and morbidity reasons in patients. For this reason, recognition of infectious agents and their resistance to antimicrobials in intensive care unit (ICU) is very important for rational antibiotic use. The present study aimed to investigate the types of HAls, causative microorganisms, resistance patterns, and risk factors, and to identify their impacts on mortality in Anesthesiology, Intensive Medicine, Neurology, General Surgery, and Orthopedics ICUs in Atatürk University, Faculty of Medicine, Research Hospital. Materials and Methods: Patients who were diagnosed as having HAI in ICUs between 1 June 2019-30 November 2019 were evaluated prospectively. Demographic data, types of grown pathogens, and resistance rates were recorded. The impact of variables on mortality was investigated.

Results: One hundred and sixty five HAls were diagnosed in 81 patients, out of 1.078 patients admitted to ICUs. The mean age of patients who developed HAI was $65.2 \pm 15.7$ years, while the mean age of patients who lost their lives was $67.5 \pm 15.3$ years. The mean age of the patients who died was significantly higher than the patients who were discharged $(p=0.028)$. There was a significant relationship between risk factors including chronic obstructive pulmonary disease, congestive heart failure, mechanical ventilation, and endotracheal intubation, and mortality ( $p=0.047, p=0.047$, $p=0.04$, and $p=0.002$, respectively). Hospital-acquired infection was found to be significantly related with mortality in ICU patients o ( $<<0.001$ ). The most common types of infections were found to be catheter-related bloodstream infection (41.8\%), ventilator-associated pneumonia (22.4\%) and catheter-related urinary tract infection (20\%). Gram-negative bacteria or agents were causative in 71.5\% of HAls, Gram-positive bacteria or agents 24.2\%, and Candida spp. 4.2\%. The most frequently isolated Gram-negative bacteria were Acinetobacter spp., Klebsiella pneumonia and Pseudomonas aeruginosa. In terms of antibiotic resistances, carbapenem resistance was found to be 100\% in Acinetobacter spp. strains. Extended spectrum beta-lactamase was produced in 70.5\% of Escherichia coli strains and 77.7\% of Klebsiella pneumoniae strains. Vancomycin resistance was not found in Enterococcus.

Conclusion: It is of the utmost importance for each center to monitor their own flora, causative microorganisms, and antibiotic resistances alongside with surveillance studies for the control of HAls. This will ensure the use of suitable antibiotics in empirical treatment. It is necessary to increase compliance with infection control standards in ICUs and to avoid unnecessary invasive procedures. In this way, a decrease in HAls that cause increased morbidity and mortality can be achieved.

Keywords: Hospital-acquired infections, antibiotic resistances, mortality

Cite this article as: Borulu B, Parlak E, Yılmaz S, Borulu F, Parlak M. The Causative Agents, Their Antimicrobial Susceptibilities and Their Effects on Mortality of Intensive Care Infections in Atatürk University Medical Faculty Research Hospital. Mediterr J Infect Microb Antimicrob. 2021;10:33. 
Giriş: Hastane enfeksiyonları (HE), hastalar için önemli morbidite ve mortalite nedenidir. Yoğun bakım ünitesinin (YBÜ) enfeksiyon etkenleri ve antimikrobiyal direnç durumunun bilinmesi rasyonel antibiyotik kullanımı açısından çok önemlidir. Çalışmamızda, Atatürk Üniversitesi Tıp Fakültesi Hastanesi'ndeki Anesteziyoloji, Dahiliye, Nöroloji, Genel Cerrahi ve Ortopedi YBÜ'lerinde gelişen HE türlerinin, etken mikroorganizmaların, direnç paternlerinin ve risk faktörlerinin incelenmesi ve bunların mortalite üzerine etkilerinin belirlenmesi amaçlandı.

Gereç ve Yöntem: Yoğun bakım ünitelerinde 1 Haziran 2019-30 Kasım 2019 tarihleri arasında HE tanısı konulan hastalar prospektif olarak değerlendirildi. Demografik veriler, üreyen patojenlerin türleri ve direnç oranları kaydedildi. Değişkenlerin mortalite üzerine etkisi incelendi.

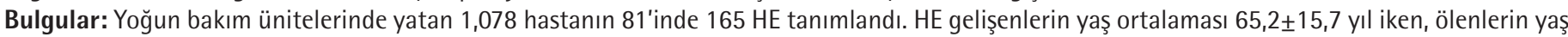
ortalaması $67,5 \pm 15,3$ yıl ile anlamlı olarak daha yüksekti $(p=0,028)$. Risk faktörlerinden kronik obstrüktif akciğer hastalığı, konjestif kalp yetmezliği, mekanik ventilasyon ve endotrakeal entübasyon varlığının mortalite üzerine etkisi anlamlı bulundu (sırasıyla; $p=0,047, p=0,047, p=0,04$ ve $p=0,002$ ). Yoğun bakım hastalarında HE gelişme durumunun mortalite üzerine etkisi anlamlı bulundu $(p<0,001)$. En sık görülen enfeksiyon türleri kateter ilişkili kan dolaşım enfeksiyonu $(\% 41,8)$, ventilatör ilişkili pnömoni $(\% 22,4)$ ve kateter ilişkili üriner sistem enfeksiyonu (\%20) olarak saptandı. Gramolumsuz etkenler \%71,5, Gram-olumlular \%24,2 ve Candida spp. \%4,2 oranında saptandı. En sık izole edilen Gram-olumsuz bakteriler; Acinetobacter spp., Klebsiella pneumonia ve Pseudomonas aeruginosa idi. Gram-olumlu bakteriler içinde Enterococcus spp. ilk sırayı aldı. Antibiyotik dirençleri değerlendirildiğinde Acinetobacter suşlarında karbapenem direnci \%100 bulundu. Escherichia coli suşlarında genişlemiş spektrumlu beta-laktamaz oranı \%70,5; Klebsiella pneumonia suşlarında ise \%77,7 saptandı. Enterokoklarda vankomisin direnci saptanmadı.

Sonuç: Hastane enfeksiyonlarının kontrolü için sürveyans çalışmaları ile her merkezin kendi florasını, etken mikroorganizmaları ve antibiyotik duyarlılıklarını takip etmesi önemlidir. Bu durum ampirik tedavide doğru antibiyotik kullanımını sağlayacaktır. YBÜ'lerde enfeksiyon kontrol standartlarına uyumun artırılması ve gereksiz invaziv girişimlerden kaçınılması gerekmektedir. Bu şekilde morbidite ve mortalite artışına neden olan HE'lerde azalma sağlanabilir.

Anahtar Kelimeler: Hastane enfeksiyonları, antibiyotik dirençleri, mortalite

\section{Introduction}

Infections that are not in the incubation period when hospitalized, develop 48-72 hours after hospitalization and within 10 days after discharge are hospital-acquired infections $(\mathrm{HAls})^{[1]}$. HAl is one of the serious health problems in our country as well as all over the world ${ }^{[2,3]}$. HAl increases the length of hospital stay, morbidity, mortality, and cost ${ }^{[4,5]}$.

Intensive care units (ICUs) are the units where HAl is most common and mortality is highest. Intensive care units are highrisk units for $\mathrm{HAl}$, and $20-25 \%$ of HAls develop in these units ${ }^{[3]}$. Known risk factors for $\mathrm{HAl}$ in ICU include use of invasive devices [central venous catheter (CVC), urinary catheter, mechanical ventilator, nasogastric tube], tracheostomy, underlying diseases, comorbid conditions, and length of stay ${ }^{[6]}$.

Due to the high-risk patient follow-up in ICUs, empiric antibiotic therapy often has to be started without waiting for the isolation of the causative agents ${ }^{[6]}$. The high infection rate in these units and the broad-spectrum antibiotics used in their treatment cause the emergence of resistant agents and serious problems in treatment. These resistant microorganisms increase morbidity and mortality ${ }^{[7]}$.

Knowing the distribution of microorganisms in their flora, their resistance patterns and risk factors, and initiation of appropriate empirical treatment will reduce morbidity and mortality ${ }^{[6]}$.

Knowing the rates of invasive device use and infection rates in ICU are the best methods used to compare infection rates within and between hospitals ${ }^{[8]}$.
This study was conducted to determine the effects of HAI, causative agents, antimicrobial susceptibilities and risk factors on mortality in patients hospitalized in Internal Medicine, Neurology, General Surgery, Orthopedics and Anesthesiology and Reanimation ICUs between 1 June 2019 and 30 November 2019.

\section{Materials and Methods}

Among the patients who were followed up and treated in the Anesthesiology and Reanimation, Internal Medicine, Neurology, General Surgery and Orthopedics ICUs of Atatürk University Faculty of Medicine Research Hospital between 1 June 2019 and 30 November 2019, those who developed an infection after at least 48 hours of hospitalization were considered as having HAl and included in the study. Consent was obtained from the patients and/or their relatives. The study design was descriptive and prospective. The study was approved by the Ethics Committee of Atatürk University (date 30.05.2019; meeting number: 04; decision no: 01).

There were 50 beds in total in the ICUs included in the study, of which 17 were in Anesthesiology ICU, nine in Internal Medicine ICU, eight in Neurology ICU, 10 in General Surgery ICU, and six in Orthopedics ICU.

All ICUs were regularly visited by a faculty member, a research assistant and an infection control nurse from the Department of Infectious Diseases. Diagnostic criteria of the Centers for Disease Control and Prevention (CDC) and National Nosocomial Infections Surveillance Network were used for diagnosis of HAI.

The data of the patients including; age, gender, diagnosis of hospitalization, hospitalization dates, length of stay, ICU in 
which the patient was hospitalized, underlying comorbid diseases [diabetes mellitus, congestive heart failure, coronary artery disease, chronic obstructive pulmonary disease (COPD), chronic kidney failure, malignancy], diet [total parenteral nutrition (TPN)], hemodialysis, invasive interventions (urinary catheter, CVC, endotracheal intubation, mechanical ventilation, tracheostomy, nasogastric tube), and type of discharge from ICU (death/discharge) were recorded.

In calculating the HAI rate, the formula of dividing the number of HAl detected in a certain period by the number of patients in the same period and multiplying by 100 was used. While calculating the HAI incidence density, the formula of dividing the number of HAl occurring in a certain period by the patient days in the same period and multiplying by 1,000 was used ${ }^{[5]}$.

Microbiological samples were inoculated on sheep blood agar, eosin methylene blue, and samples were inoculated on two chocolate agars, if necessary. The BD BACTEC system was used for blood culture. The samples were incubated in an oven at $35{ }^{\circ} \mathrm{C}$ for approximately $18-24$ hours. After the evaluation, bacterial identification and susceptibility studies were started.

Bacteria identifications were made with conventional biochemical tests and BD Phoenix device. Susceptibility studies were organized according to the European Committee on Antimicrobial Susceptibility Testing V.8.1. The results obtained conventionally were studied by the disk diffusion method. Germ tube test of yeasts grown in blood cultures, colony appearance on corn meal agar, color difference on chromogenic agar and species identification with BD Phoenix device were performed. Antifungal susceptibility test of yeasts was performed with liquid microdilution with the Sensititre YeastOne Y010 kit in line with the company's recommendations.

\section{Statistical Analysis}

Statistical Package for the Social Sciences v20 was used to analyze the data. Categorical variables were presented as numbers and percentages, and numerical variables as mean and standard deviation. The normal distribution of the numerical variables was investigated using the Kolmogorov-Smirnov test, $z$ values calculated for skewness and kurtosis, and graphing methods. Mann-Whitney U test was used for comparisons of numerical variables without normal distribution between two groups. $\chi^{2}$ test was used for comparison of distributions of categorical variables and Fisher's Exact test was used when necessary. The statistical significance level in the analysis was accepted as $p<0.05$.

\section{Results}

In this study, 81 patients who were diagnosed as having HAl based on CDC diagnostic criteria among 1,078 patients hospitalized in the Anesthesiology and Reanimation, Internal Medicine, General Surgery, Neurology and Orthopedics ICUs between 1 June 2019-30 November 2019 were included in the study. A total of 165 HAls were identified in these patients. Of the patients included in the study, 34 were hospitalized in Anesthesiology and Reanimation ICU, 16 in Internal Medicine ICU, 14 in Neurology ICU, 10 in General Surgery ICU, and seven in Orthopedics ICU.

While the mean age of the patients was $65.2 \pm 15.7$ years, 41 $(50.6 \%)$ were women. Age distributions were similar by gender ( $p>0.05$ ). The mean age of patients discharged from ICUs was $61.2 \pm 15.8$ years, and the mean age of those who died was $67.5 \pm 15.3$ years. When the age distribution of the patients according to their discharge status from ICU was examined, it was observed that the average age of the patients who died was higher $(p=0.028)$.

While the mean hospital stay was $46.1 \pm 49.3$ days in those who developed HAl, this duration was calculated as $38.9 \pm 38.9$ days in women and $53.4 \pm 57.7$ days in men. No significant difference was found in terms of mortality and length of stay according to the gender of the patients ( $p>0.05)$. The mean length of stay for those discharged from ICU was $39.2 \pm 27.1$ days, and the mean hospital stay for those who died was $50.1 \pm 58.5$ days. There was no difference between the patients who were discharged from ICU and those who died in terms of hospitalization duration ( $p>0.05)$.

Considering the preliminary diagnoses of admission to the ICU, the most common was neurological diseases which was in 25 patients (30.9\%). Trauma was the second most common preliminary diagnosis. There were significant relationships between mortality and the presence of COPD and congestive heart failure ( $p=0.047$ and $p=0.047)$, mechanical ventilation and endotracheal intubation as invasive procedures $(p=0.004$ and $p=0.002)$, and TPN as a risk factor $(p=0.035)$ (Table 1$)$.

It was observed that the development of HAl had a significant effect on mortality $(p<0.001)$ (Figure 1). Distribution of HAI types, infection rates and incidence densities according to ICUs are shown (Table 2).

The general distribution of HAl agents is given in Figure 2. Of the agents isolated in Gram-negative bacteria, 46 (38.9\%) were Acinetobacter spp., 21 (17.7\%) were K. pneumoniae, and 18 (15.2\%) were $P$. aeruginosa. Extended-spectrum beta-lactamase rate (ESBL) in Escherichia coli strains was 70.5\% and it was detected in $77.7 \%$ of Klebsiella pneumoniae strains. Of those isolated in Gram-positive bacteria, 28 (70\%) were Enterococcus spp. and nine (22.5\%) were found to be methicillin-resistant coagulase-negative staphylococci (MRCNS). Acinetobacter spp. (27.9\%) and Enterococcus spp. (17\%) were the most common causes of HAl. Candida spp. the incidence was found to be $4.2 \%$. 
The distribution of the factors according to the ICUs is shown in Table 3.

The most common factor causing ventilator-associated pneumonia (VAP) was Acinetobacter spp. (51.3\%), the second most common factor was $P$. aeruginosa (27\%). Enterococcus spp. (24.6\%), Acinetobacter spp. (21.7\%) and MRCNS (11.5\%) were the most common agents isolated in catheter-related bloodstream infections (CRBSI). The most common agents isolated in catheter-related urinary tract infection (CRUTI) were Enterococcus spp. (27.2\%) and E. coli (21.2\%). The two most common agents causing surgical site infection (SSI) were Acinetobacter spp. (26.6\%) and E. coli (26.6\%). The two most common agents causing skin and soft tissue infection were Acinetobacter spp. (27.2\%) and K. pneumoniae (27.2\%). Distribution of microorganisms in all ICUs according to infection types is shown in Table 4.

Table 1. Association of underlying diseases and invasive procedures with mortality

\begin{tabular}{llll}
\hline Underlying disease & $\begin{array}{l}\text { Number } \\
(\mathbf{n})\end{array}$ & $\begin{array}{l}\text { Percentage } \\
\mathbf{( \% )}\end{array}$ & p value \\
\hline Hypertension & 34 & 42 & $>0.05$ \\
\hline Diabetes mellitus & 19 & 23 & $>0.05$ \\
\hline Malignancy & 18 & 22 & $>0.05$ \\
\hline Coronary artery disease & 13 & 16 & $>0.05$ \\
\hline $\begin{array}{l}\text { Chronic obstructive pulmonary } \\
\text { disease }\end{array}$ & 11 & 14 & $\mathbf{0 . 0 4 7}$ \\
\hline Congestive heart failure & 11 & 14 & $\mathbf{0 . 0 4 7}$ \\
\hline Chronic renal failure & 9 & 11 & $>0.05$ \\
\hline Invasive procedure & & & \\
\hline Urinary catheter & 80 & 98.7 & $>0.05$ \\
\hline Central venous catheter & 61 & 75.3 & $>0.05$ \\
\hline Mechanical ventilation & 56 & 69.1 & $\mathbf{0 . 0 0 4}$ \\
\hline Endotracheal intubation & 50 & 61.7 & $\mathbf{0 . 0 0 2}$ \\
\hline Nasogastric tube & 41 & 50.6 & $>0.05$ \\
\hline Tracheostomy & 11 & 13.5 & $>0.05$ \\
\hline Total parenteral nutrition & 15 & 86.7 & $\mathbf{0 . 0 3 5}$ \\
\hline
\end{tabular}

Of the Enterococci strains 100\% were resistant to ampicillin, and 83.3\% were resistant to ciprofloxacin and levofloxacin. Vancomycin and linezolid resistance was not observed. Highlevel gentamicin resistance was found in 53.5\%, and high-level streptomycin resistance were found in $46.5 \%$ of the Enterococci strains.

Antibiotic resistances of Gram-negative pathogens in all ICUs are given in Table 5 .

Three of the Candida strains causing HAl were found as Candida albicans and 4 as Candida parapsilosis. Fluconazole,

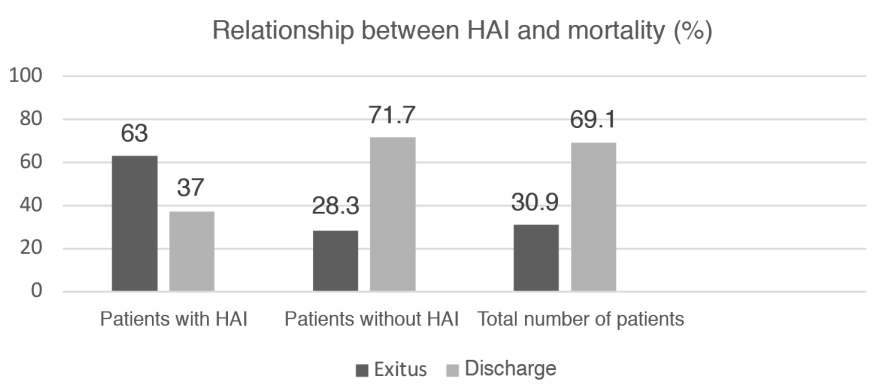

Figure 1. Comparison of mortality/discharge status in patients with and without hospital-acquired infection

HAl: Hospital-acquired infection

\section{Causative pathogens (\%)}

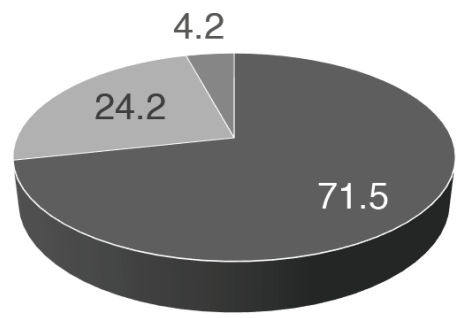

- Gram-negative - Gram-positive - Candida

Figure 2. Distribution of causative pathogens

Table 2. Distribution of hospital-acquired infection types, infection rates and incidence densities according to intensive care units

\begin{tabular}{|c|c|c|c|c|c|c|c|c|c|c|}
\hline & $\begin{array}{l}\text { VAP } \\
\text { n (\%) }\end{array}$ & $\begin{array}{l}\text { CRBSI } \\
\text { n (\%) }\end{array}$ & $\begin{array}{l}\text { CRUTI } \\
\text { n (\%) }\end{array}$ & $\begin{array}{l}\text { SSI } \\
\text { n (\%) }\end{array}$ & $\begin{array}{l}\text { SSTI } \\
\text { n (\%) }\end{array}$ & $\begin{array}{l}\text { Number of } \\
\text { patients }\end{array}$ & $\begin{array}{l}\text { Patient } \\
\text { days }\end{array}$ & $\begin{array}{l}\text { Number } \\
\text { of } \\
\text { infections }\end{array}$ & $\begin{array}{l}\text { Infection } \\
\text { rate }\end{array}$ & $\begin{array}{l}\text { Infection } \\
\text { incidence } \\
\text { density }\end{array}$ \\
\hline Anesthesiology ICU & $26(38.8)$ & $29(43.3)$ & 8 (11.9) & $0(0)$ & $4(6.0)$ & 248 & 2,327 & 67 & 27 & 28.7 \\
\hline Internal medicine ICU & $5(19.2)$ & $12(46.2)$ & $6(23.1)$ & $0(0)$ & $3(11.5)$ & 237 & 1,216 & 26 & 10.9 & 21.3 \\
\hline Neurology ICU & $3(7.1)$ & $20(47.6)$ & $16(38.1)$ & $0(0)$ & $3(7.1)$ & 94 & 1,275 & 42 & 44.6 & 32.9 \\
\hline General surgery ICU & $3(15.0)$ & $7(35.0)$ & $3(15.0)$ & $7(35.0)$ & $0(0)$ & 293 & 922 & 20 & 6.8 & 21.6 \\
\hline Orthopedics ICU & $0(0)$ & $1(10.0)$ & $0(0)$ & $8(80.0)$ & $1(10.0)$ & 206 & 622 & 10 & 4.8 & 16.0 \\
\hline Total & 37 (22.4) & 69 (41.8) & $33(20)$ & 15 (9) & 11 (6.6) & 1,078 & 6,392 & 165 & & \\
\hline
\end{tabular}

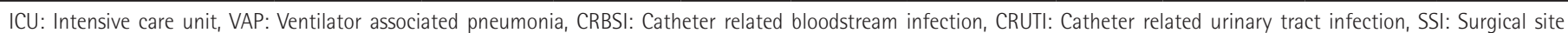
infection, SSTI: Skin-soft tissue infection, ICU: Intensive care unit 
voriconazole, caspofungin, micafungin and anidulafungin resistance were not detected in any of the strains.

\section{Discussion}

Patients in ICUs constitute the highest risk group for the development of infection in the hospital because of their underlying diseases, organ failures, and invasive procedures applied for diagnosis and treatment ${ }^{[0]}$. Knowing the causative microorganisms and their antibiotic susceptibility in ICUs is also helpful in reducing morbidity and mortality ${ }^{[10]}$.

Kölgelier et al. ${ }^{[2]}$ found that $60.3 \%$ of the patients who developed $\mathrm{HAI}$ in the ICU were male and 39.7\% female. Although Erbay et al. ${ }^{[6]}$ found that the presence of male gender was a risk factor for the development of $\mathrm{HAl}$, similar to other studies in the literature, no significant relationship was found between gender and $\mathrm{HAl}$ in our study.

Table 3. Distribution of isolated agents according to intensive care units

\begin{tabular}{|c|c|c|c|c|c|}
\hline & $\begin{array}{l}\text { Anesthesiology } \\
\text { ICU }\end{array}$ & $\begin{array}{l}\text { Internal medicine } \\
\text { ICU }\end{array}$ & Neurology ICU & $\begin{array}{l}\text { General surgery } \\
\text { ICU }\end{array}$ & $\begin{array}{l}\text { Orthopedics } \\
\text { ICU }\end{array}$ \\
\hline Acinetobacter n (\%) & $26(38.8)$ & $4(15.4)$ & $8(19.0)$ & $5(25.0)$ & $3(30.0)$ \\
\hline K. pneumoniae $\mathrm{n}(\%)$ & $12(17.9)$ & $1(3.8)$ & $5(11.9)$ & & $3(30.0)$ \\
\hline K. oxytoca n (\%) & $4(6)$ & $1(3.8)$ & $1(2.4)$ & $1(5.0)$ & \\
\hline E. coli n (\%) & & $6(23.1)$ & $5(11.9)$ & $4(20.0)$ & $2(20.0)$ \\
\hline Pseudomonas n (\%) & $11(16.4)$ & $2(7.7)$ & $4(9.5)$ & & $1(10.0)$ \\
\hline Enterobacter n (\%) & & $1(3.8)$ & $2(4.8)$ & $1(5.0)$ & \\
\hline Proteus n (\%) & $3(4.5)$ & & $2(4.8)$ & & \\
\hline MSKNS n (\%) & & $1(3.8)$ & & & \\
\hline MRKNS n (\%) & $2(3.0)$ & $2(7.7)$ & $2(4.8)$ & $3(15.0)$ & \\
\hline MSSA n (\%) & & & $1(2.4)$ & & \\
\hline MRSA n (\%) & & $1(3.8)$ & & & \\
\hline Enterococcus $\mathrm{n}(\%)$ & $6(9.0)$ & $4(15.4)$ & $12(28.6)$ & $6(30.0)$ & \\
\hline Candida n (\%) & $3(4.5)$ & $3(11.5)$ & & & $1(10.0)$ \\
\hline
\end{tabular}

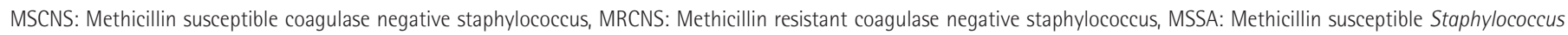
aureus, MRSA: Methicillin resistant Staphylococcus aureus, ICU: Intensive care unit

Table 4. Distribution of microorganisms in all intensive care units according to infection types

\begin{tabular}{|c|c|c|c|c|c|c|c|c|c|c|}
\hline Microorganisms & $\begin{array}{l}\text { VAP } \\
\text { (n) }\end{array}$ & $\begin{array}{l}\text { VAP } \\
(\%)\end{array}$ & $\begin{array}{l}\text { CRBSI } \\
\text { (n) }\end{array}$ & $\begin{array}{l}\text { CRBSI } \\
(\%)\end{array}$ & $\begin{array}{l}\text { CRUTI } \\
\text { (n) }\end{array}$ & $\begin{array}{l}\text { CRUTI } \\
(\%)\end{array}$ & SSI (n) & $\begin{array}{l}\text { SSI } \\
(\%)\end{array}$ & $\begin{array}{l}\text { SSTI } \\
\text { (n) }\end{array}$ & $\begin{array}{l}\text { SSTI } \\
(\%)\end{array}$ \\
\hline Acinetobacter & 19 & 51.3 & 15 & 21.7 & 5 & 15.1 & 4 & 26.6 & 3 & 27.2 \\
\hline K. pneumoniae & 5 & 13.5 & 7 & 10.1 & 3 & 9.0 & 3 & 20.0 & 3 & 27.2 \\
\hline K. oxytoca & 1 & 2.7 & 4 & 5.7 & 1 & 3.0 & 1 & 6.6 & 0 & 0 \\
\hline E. coli & 1 & 2.7 & 3 & 4.3 & 7 & 21.2 & 4 & 26.6 & 2 & 18.1 \\
\hline Pseudomonas & 10 & 27.0 & 2 & 2.8 & 4 & 12.1 & 1 & 6.6 & 1 & 9.0 \\
\hline Enterobacter & 1 & 2.7 & 0 & 0 & 3 & 9.0 & 0 & 0 & 0 & 0 \\
\hline Proteus & 0 & 0 & 3 & 4.3 & 1 & 3.0 & 0 & 0 & 1 & 9.0 \\
\hline MSKNS & 0 & 0 & 1 & 1.4 & 0 & 0 & 0 & 0 & 0 & 0 \\
\hline MRKNS & 0 & 0 & 8 & 11.5 & 0 & 0 & 1 & 6.6 & 0 & 0 \\
\hline MSSA & 0 & 0 & 1 & 1.4 & 0 & 0 & 0 & 0 & 0 & 0 \\
\hline MRSA & 0 & 0 & 1 & 1.4 & 0 & 0 & 0 & 0 & 0 & 0 \\
\hline Enterococcus & 0 & 0 & 17 & 24.6 & 9 & 27.2 & 1 & 6.6 & 1 & 9.0 \\
\hline Candida & 0 & 0 & 7 & 10.1 & 0 & 0 & 0 & 0 & 0 & 0 \\
\hline Total & 37 & 100 & 69 & 100 & 33 & 100 & 15 & 100 & 11 & 100 \\
\hline
\end{tabular}

ICU: Intensive care unit, VAP: Ventilator associated pneumonia, CRBSI: Catheter related bloodstream infection, CRUTI: Catheter related urinary tract infection, SSI: Surgical site infection, SSTI: Skin-soft tissue infection, MSCNS: Methicillin susceptible coagulase negative staphylococcus, MRCNS: Methicillin resistant coagulase negative staphylococcus, MSSA: Methicillin susceptible Staphylococcus aureus, MRSA: Methicillin resistant Staphylococcus aureus 


\begin{tabular}{|c|c|c|c|c|c|c|c|c|c|c|c|c|c|c|c|c|c|}
\hline Patojenler & 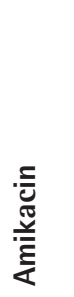 & 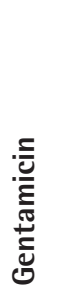 & 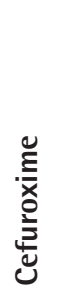 & 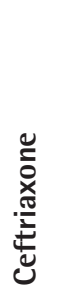 & 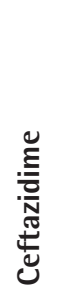 & 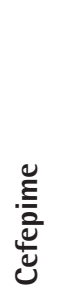 & 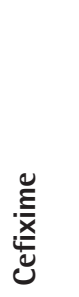 & 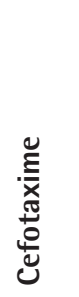 & $\frac{\text { 竞 }}{\frac{0}{\frac{e}{2}}}$ & 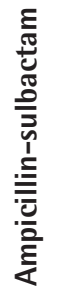 & \begin{tabular}{l}
$\sqrt[5]{\nwarrow}$ \\
\multirow{1}{1}{} \\
$\sum_{1}^{\prime}$
\end{tabular} & 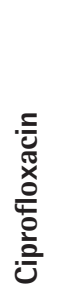 & 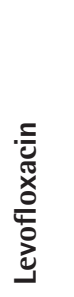 & $\begin{array}{l}\stackrel{n}{N} \\
\frac{1}{\alpha}\end{array}$ & 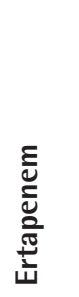 & 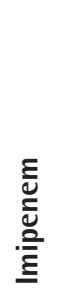 & 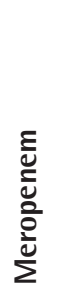 \\
\hline Acinetobacter $(n=46)$ & 84.7 & 73.9 & - & - & - & - & - & - & - & 65.7 & 58.7 & 100 & - & - & - & 100 & 100 \\
\hline K. pneumoniae $(n=21)$ & 42.8 & 71.4 & 95.4 & 85.7 & 80.9 & 85.7 & 66.6 & 71.4 & 100 & 90.4 & 95.2 & 90.4 & 84.6 & 85.7 & 63.1 & 19.0 & 42.8 \\
\hline K. oxytoca $(n=7)$ & 0 & 28.5 & 85.7 & 57.1 & 28.5 & 42.8 & 66.6 & 100 & 100 & 85.7 & 71.4 & 42.8 & 0 & 57.1 & 28.5 & 0 & 0 \\
\hline E. coli $(n=17)$ & 0 & 64.7 & 88.2 & 82.3 & 88.2 & 76.4 & 90.0 & 90.0 & 100 & 52.9 & 64.7 & 76.4 & 100 & 58.8 & 6.2 & 0 & 0 \\
\hline Pseudomonas $(n=18)$ & 0 & 0 & - & - & 22.2 & 11.1 & - & - & - & - & - & 18.7 & - & 66.6 & - & 44.4 & 44.4 \\
\hline Enterobacter $(n=4)$ & 0 & 50.0 & 75.0 & 75.0 & 75.0 & 75.0 & 66.6 & 66.6 & - & 50.0 & 25.0 & 25.0 & - & 75.0 & 50.0 & 25.0 & 25.0 \\
\hline Proteus $(\mathrm{n}=5)$ & 40.0 & 80.0 & 40.0 & 40.0 & 40.0 & 40.0 & 50.0 & 50.0 & 100 & 40.0 & 100 & 80.0 & 100 & 20.0 & 0 & 0 & 0 \\
\hline
\end{tabular}

TMP-SXT: Trimethoprim-sulfamethoxazole, PIP-TZB: Piperacillin tazobactam

In a study conducted in ICUs in 2012, the mean age of patients was found to be $61.2 \pm 19.2$ years. The mean age of those who died was found to be significantly higher than those who were discharged ${ }^{[2]}$. Kaya et al. ${ }^{[11]}$ showed that the mean hospitalization period of those who developed HAl was $15.6 \pm 20.4$ days, and a significant correlation was found between the length of hospital stay and mortality. Again, in the same study, age and mortality rates were compared and the increase in the mortality rate in elderly patients was found to be statistically significant. In our study, when the relationship between length of stay and mortality was examined, no significant relationship was found. Similar to these two studies, in our study, when the age distribution of patients according to mortality was examined, it was seen that the average age of those who died was higher.

Patients hospitalized in ICUs are usually patients with one or more underlying chronic diseases. This situation has an effect on increasing the possibility of infection in patients. Meric et al. ${ }^{[12]}$ showed that there was a relationship between the number of underlying diseases and the development of HAI. In another study, cerebrovascular disease, diabetes, congestive heart failure and COPD were found to be the most common underlying diseases, respectively ${ }^{[13]}$. In our study, hypertension was the most common comorbid risk factor in patients with HAl, followed by diabetes mellitus, malignancy and coronary artery disease.

When the relationship between the underlying disease and mortality was evaluated in a study, it was found that mortality was higher in patients with diabetes mellitus and renal failure ${ }^{[2]}$. In our study, the effects of COPD and congestive heart failure on mortality were found to be significant.

Kaya et al. ${ }^{[11]}$ also identified mechanical ventilation as a risk factor for mortality. In another study, invasive procedures were evaluated and it was found that the presence of a central catheter and intubation were effective on mortality ${ }^{[2]}$. In our study, invasive procedures associated with mortality were determined as mechanical ventilation and endotracheal intubation.

Parenteral nutrition can often precede enteral nutrition in patients treated in ICUs for a long time. This situation both causes unnecessary CVC placement and leads to regressions in the functions of the gastrointestinal system ${ }^{[14]}$. In patients in ICU, it is necessary to switch to enteral nutrition as soon as possible. The statistically significant effect of TPN on mortality in this study showed once again that this issue was important.

These infections that develop in the ICU can cause serious increases in both mortality and treatment costs ${ }^{[15]}$. Şahin et al. ${ }^{[16]}$ also found that mortality was $56.6 \%$ in the group with HAI and $22.7 \%$ in the group without $\mathrm{HE}$, and it was shown that there was a statistically significant relationship between the development of $\mathrm{HAl}$ and the increase in mortality. Agarwal et al. ${ }^{[17]}$ found that $56.7 \%$ of the patients who developed HAI died and there was a significant correlation between HAI and mortality. In our study, $63 \%$ of the patients diagnosed as having $\mathrm{HAl}$ died and $37 \%$ were discharged, while of the patients who did not develop HAI, $28.3 \%$ died and $71.7 \%$ were discharged. When we looked at our study data, it was seen that the effect of HAI on mortality was significant, similar to the literature.

Şahin et al. ${ }^{[16]}$ showed the highest infection density in the Anesthesiology ICU with a rate of 20.34, while the Neurosurgery ICU came in second with a rate of 17.79. In the Neurology ICU, this rate was calculated as 9.73. Öncül et al. ${ }^{[18]}$ In the study, the rate of HAl was found to be the highest in Anesthesiology ICU and Neurology ICU with the rates of $35.1 \%$ and $31.9 \%$. In 
our study, the rate of HAl was found to be the highest in the Neurology and Anesthesiology ICUs with the rates of $44.6 \%$ and $27 \%$. We attributed the high rate of HAI in the Anesthesiology ICU to the hospitalization of more severe patients who needed ventilator respiratory support and trauma patients compared to other units, and to the more application of invasive interventions. We thought that the high rate of $\mathrm{HAl}$ in the Neurology ICU was due to the long-term mechanical ventilation and endotracheal intubation support due to the neurological diagnosis of the hospitalized patients and the long hospitalization periods. These prolonged hospitalizations caused recurrent episodes of HAl.

The urinary tract infection (UTI), bloodstream infection (BSI) and VAP are the most common infections in patients treated in the ICU. Barış et al. ${ }^{[19]}$ found that CRBSI was the most common with a rate of $41.9 \%$, followed by CRUTI with $20 \%$ and VAP with 19.2\%. In the distribution of 165 HAls detected in our study according to the types of infection, CRBSI was the most common one with $41.8 \%$. The second most common type of infection was VAP with $22.4 \%$, and the third most common type was CRUTI with $20 \%$. As in the studies in the literature, BSI and VAP were found to be the most common infections in our study. In the ICU, these infections develop due to the widespread use of invasive interventions such as $\mathrm{CVC}$ placement and mechanical ventilators, and non-compliance with infection control rules, and cross-contamination caused by healthcare personnel.

Balın and Şeno ${ }^{[20]}$ showed that the most common infection was CRBSI with $48.8 \%$, which was followed by VAP with $29.1 \%$, UTI with $21.2 \%$, and SSI with $0.7 \%$ in Anesthesiology ICU. In another study performed in the Anesthesiology ICU, the most common HAls were BSI, UTI, SSI, and VAP, respectively ${ }^{[11]}$. In our study, similar to many studies in the literature, when the distribution of infection types according to ICUs was examined, it was seen that the most common HAI was CRBSI with a rate of $43.3 \%$ and that the second most common HAI was VAP with a rate of $38.8 \%$ in the Anesthesiolgy and Reanimation ICU.

In the EPIC II study, in which 1265 ICUs in 75 countries participated, $62 \%$ of the isolated agents were Gram-negative bacteria, 47\% Gram-positive bacteria, and 19\% Candida ${ }^{[21]}$. Büyüktuna et al. ${ }^{[22]}$ found that $64.5 \%$ of the isolated pathogens were Gram-negative bacteria, 24.7\% Gram-positive bacteria and $10.7 \%$ Candida spp. in the ICUs. Barış et al. ${ }^{[19]}$ found that $49.4 \%$ of isolated pathogens were Gram-negative bacteria, 47.8\% were Gram-positive bacteria, and 2.7\% were Candida species. Among Gram-positive bacteria, coagulase negative Staphylococcus spp. (CNS) were the most common with 30\%, followed by Enterococcus spp. with 9.5\% and S. aureus with $4.7 \%$, respectively. Büyüktuna et al. ${ }^{[22]}$ found that Pseudomonas spp. were the most common isolated pathogens, followed by Acinetobacter spp. and Klebsiella spp. Agarwal et al. ${ }^{[17]}$ found in their study in the ICU that Acinetobacter spp. were causative in $34.8 \%$ of HAls, P. aeruginosa in $23.9 \%$, E. coli in $15.2 \%$, and MRSA in $8.7 \%$. While staphylococci were the most common Gram-positive pathogens in those studies, Enterococcus spp. were the most common Gram-positive pathogens in our study. It was thought that the reason for the high rate of Enterococcus spp. infections was the increase in the empirical use of third generation cephalosporin and carbapenem due to the increasing resistance problem in microorganisms in the hospital. In addition, we thought that the predominance of CNS strains in some studies might be due to the fact that this pathogen was a member of the skin flora, and it was not easy to distinguish between contamination and causative agents, and some contaminations were considered as agents in retrospective studies. Since our study was a prospective study, the clinical and laboratory findings of the patients were evaluated simultaneously during the detection of growth, and the differentiation between the agent and colonization could be made more clearly.

Büyüktuna et al. ${ }^{[22]}$ found that Acinetobacter spp. and Pseudomonas spp. were the most common agents causing VAP. In our study, in accordance with the literature, the most common isolated agents in VAP were Acinetobacter spp. with a rate of $51.3 \%$ and $P$. aeruginosa with a rate of $27 \%$. Asepsis in the use of mechanical ventilator, environment cleaning and hand hygiene should be paid attention.

Gözütok et al. ${ }^{[23]}$ found that CNS was the most common isolated agent in CRBSI with a rate of $31.2 \%$, followed by Enterococcus spp. with 25\%, Acinetobacterspp. with 21.8\%, and Candida with $6.2 \%$. In our study, the most common agents detected in CRBSI were Enterococcus spp. with a rate of $24.6 \%$ and Acinetobacter spp. with a rate of $21.7 \%$, while the others were MRCNS with a rate of $11.5 \%$ and Candida spp. with a rate of $10.1 \%$. While CNS was considered among the most common factors for CRBSI, it was less common in our study. We thought that this was due to the fact that not every CNS that grew in the blood culture was considered as a factor, but some of it was considered as contamination based on the patient's clinic, laboratory findings, and whether there was any growth in the culture taken from the catheter simultaneously.

Erbay et al. ${ }^{[6]}$ found that the most common agents isolated in CRUTI were Candida spp., Pseudomonas spp. and E. coli. On the other hand, Dogru et al. ${ }^{[24]}$ found that the most common isolated agents in CRUTI were E. coli (38\%), Candida spp. (26\%) and Enterococcus spp. (19\%), respectively. Parlak et al. ${ }^{[25]}$ found that Candida spp. (27.2\%) and E. coli (27.2\%) were the most common isolated agents in CRUTI in ICU patients. Leone et al. ${ }^{[26]}$ found that E. coli (39\%), Pseudomonas spp. (22\%), Enterobacter spp. (15\%), Acinetobacter spp. (11\%) and Klebsiella spp. (11\%) were the isolated agents. In our study, the most common agents isolated in CRUTI were Enterococcus spp. 
with a rate of $27.2 \%$, E. coli with $21.2 \%$, Acinetobacter spp. with 15.1\%, Pseudomonas spp. with 12.1\%, Enterobacter spp. with 9\%, and K. pneumoniae with 9\%, respectively. Unlike other studies, Candida was not found among the causes of CRUTI. In international studies, Gram-negative microorganisms constitute most of the causative agents of CRUTI ${ }^{[27]}$. We think that the reason for the high detection of Candida species in some studies conducted in our country, unlike the international literature, may be due to the fact that asymptomatic candiduria, which is frequently encountered in female patients with urinary catheters, is accepted as infection.

Büyüktuna et al. ${ }^{[22]}$ found that Acinetobacter spp. (23.7\%), Pseudomonas spp. (16.3\%), and Staphylococcus spp. (13.4\%) were the isolated agents in SSI. Çelik et al. ${ }^{[28]}$ isolated E.coli as the most common cause of SSI in the surgical ICU. In our study, the two most common microorganisms among all agents were Acinetobacter spp. (26.6\%) and E. coli (26.6\%). While $E$. coli was the most common cause of SSI with a rate $42.8 \%$ in the General Surgery ICU, Acinetobacter spp. (37.5\%) and K. pneumoniae $(37.5 \%)$ were the most common causes of SSI in the Orthopedics ICU.

Göktaş et al. ${ }^{[29]}$ found that $93.7 \%$ of Klebsiella spp. produced ESBL and $70 \%$ of $E$. coli strains produced ESBL in ICU. In our study, the rate of ESBL was $77.7 \%$ in Klebsiella spp. and 70.5\% in E. coli strains.

The incidence of Candida infection in ICUs were found to vary between $8.5 \%$ and $25 \%$ in some studies in our country ${ }^{[2,22]}$. In our study, the incidence of Candida (4.2\%) was lower compared to other studies. All of the Candida strains detected as causative agents of CRBSI were found to be sensitive to azole and all echinocandins.

The limitation of the study was the short duration of the study. Because the number of patients was low, some statistical analyzes were limited.

\section{Conclusion}

Considering that antibiotic resistance rates differ from hospital to hospital and even from one unit to another, it is important to know the resistance status of bacteria that are problematic in the hospital in order to determine the appropriate antibiotic protocol in empirical treatment. Increasing resistance rates over the years require rational antibiotic use strategies. Intensive care unit infections that develop with multi-resistant microorganisms cause serious, expensive and high-mortality infections in our hospital as well as all over the world and in our country. Empirical treatment in the ICU should be guided by the susceptibility results obtained in the surveillance data.

\section{Ethics}

Ethics Committee Approval: The study was approved by the Ethics Committee of Atatürk University (date 30.05.2019; meeting number: 04; decision no: 01).

Informed Consent: Retrospective study.

Peer-review: Externally peer-reviewed.

\section{Authorship Contributions}

Surgical and Medical Practices: B.B., E.P., M.P., Concept: B.B., E.P., F.B., M.P., Design: B.B., F.B., M.P., Data Collection or Processing: B.B., E.P., F.B., Analysis or Interpretation: B.B., E.P., S.Y., F.B., Literature Search: B.B., E.P., Writing: B.B., E.P.

Conflict of Interest: No conflict of interest was declared by the authors.

Financial Disclosure: The authors declared that this study received no financial support.

\section{References}

1. Artan C, Oğuzkaya Artan M, Baykan Z. Practices and Knowledge Related to the Health Risks and the Hospital Infections of the Hospital Staff. J DU Health Sci Inst. 2015;5:6-11.

2. Kölgelier S, Küçük $A$, Demir NA, Özçimen S, Demir LS. Nosocomial infections in intensive care units: etiology and predisposing factors. Kafkas J Med Sci. 2012;1:1-5.

3. Brawley RL, Weber DJ, Samsa GP, Rutala WA. Multiple nosocomial infections. An incidence study. Am J Epidemiol. 1989;130:769-80.

4. Kundakcı A, Özkalaycı Ö, Zeyneloğlu P, Arslan H, Pirat A. Risk Factors for Nosocomial Infections in a Surgical Intensive Care Unit. Türk Yoğun Bakım Derneği Dergisi. 2014;12:25-35.

5. Parlak E, Kahveci $\mathrm{H}$, Alay HK. Nosocomial infections in neonatal intensive care unit. J Curr Pediatr. 2014;12:1-8.

6. Erbay $H_{\text {, }}$ Yalcin AN, Serin $S$, Turgut $H$, Tomatir $E$, Cetin B, Zencir M. Nosocomial infections in intensive care unit in a Turkish university hospital: a 2-year survey. Intensive Care Med. 2003;29:1482-8.

7. Taşbakan MI, Sipahi OR, Pullukçu H, Aydemir Ş, Tünger A, Yurtseven T, Büke Ç. Evaluation of Hospital Infections in Neurosurgery Intensive Care Unit. Ege Tıp Derg. 2006;45:127-30.

8. Inan D, Saba R, Yalcin AN, Yilmaz M, Ongut G, Ramazanoglu A, Mamikoglu L. Device-associated nosocomial infection rates in Turkish medical-surgical intensive care units. Infect Control Hosp Epidemiol. 2006;27:343-8.

9. Weber DJ, Raasch R, Rutala WA. Nosocomial infections in the ICU: the growing importance of antibiotic-resistant pathogens. Chest. 1999;115:3441.

10. Öztürk R. Hastane enfeksiyonları. In: Öztürk R, Saltoğlu N, Aygün G editorler Sorunlar, Yeni hedefler ve Hukuki Sorumluluk. Hastane Enfeksiyonları Korunma ve Kontrol (Sempozyum Kitabı) istanbul: 2008. p.23-9.

11. Kaya S, Öksüz H, Şenoğlu N, Doğan Z, Yıldız H. Infection Surveillances in the Anesthesiology and Reanimation Clinic of Kahramanmaras Sutcu Imam University Medical Faculty Researching Hospital. Eurasian J Med. 2007;39:103-8.

12. Meric M, Willke A, Caglayan C, Toker K. Intensive care unit-acquired infections: incidence, risk factors and associated mortality in a Turkish university hospital. Jpn J Infect Dis. 2005;58:297-302. 
13. Araç E, Kaya Ş, Parlak E, Büyüktuna SA, Baran Ai, Akgül F, Gökler ME, Aksöz $S$, Sağmak Tartar A, Tekin R, Yıldız Y, Günay E. Evaluation of Infections in Intensive Care Units: A Multicentre Point-Prevalence Study. Mikrobiyol Bul. 2019;53:364-73.

14. Çelebi D, Yılmaz E. Evidence-Based Practices in Enteral and Parenteral Nutrition in Surgical Patients and Nursing Care. IGUSABDER. 2019;7:71431.

15. Girou E, Stephan F, Novara A, Safar M, Fagon JY. Risk factors and outcome of nosocomial infections: results of a matched case-control study of ICU patients. Am J Respir Crit Care Med. 1998;157:1151-8.

16. Şahin AR, Yıldız BT, Aktemur A, Topal B, Nazik S, Ateş S. Evaluation of nosocomial infections in a neurological intensive care unit of a university hospital. J Contemp Med. 2019;9:43-7.

17. Agarwal R, Gupta D, Ray P, Aggarwal AN, Jindal SK. Epidemiology, risk factors and outcome of nosocomial infections in a Respiratory Intensive Care Unit in North India. J Infect. 2006;53:98-105.

18. Öncül $A$, Koçulu $S$, Elevli K. The epidemiology of nosocomial infections acquired in intensive care units of a state hospital. The Medical Bulletin of Şişli Etfal Hospital. 2012;46:60-6.

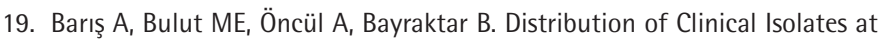
Species Level and Their Antibiotic Susceptibilities in Intensive Care Units Patients. J Turk Soc Intens Care. 2017;15:21-7.

20. Balın ŞÖ, Şenol AA. Evaluation of hospital infections in intensive care unit. Klimik Derg. 2017;30:108-13.

21. Vincent JL, Rello J, Marshall J, Silva E, Anzueto A, Martin CD, Moreno R, Lipman J, Gomersall C, Sakr Y, Reinhart K; EPIC II Group of Investigators. International study of the prevalence and outcomes of infection in intensive care units. JAMA. 2009;302:2323-9.
22. Büyüktuna AS, Yalçın Nevzat A, Turhan Ö, Cengiz M, Ramazanoğlu A. Nosocomial infections and agents determined by consultations in intensive care unit. Trakya Univ Tip Fak Derg. 2010;27:150-5.

23. Gözütok F, Sarıgüzel FM, Aydın B, Güzel DK, Kılıç İ, Gençaslan S, Çelik i. Kayseri Eğitim ve Araştırma Hastanesi Dahiliye Yoğun Bakım Ünitesin'nde 2013 yılında gelişen hastane enfeksiyonlarının değerlendirilmesi. Ankem Derg. 2014;28:86-93.

24. Dogru A, Sargin F, Celik M, Sagiroglu AE, Goksel MM, Sayhan H. The rate of device-associated nosocomial infections in a medical surgical intensive care unit of a training and research hospital in Turkey: one-year outcomes. Jpn J Infect Dis. 2010;63:95-8.

25. Parlak $E_{1}$ Erol $S$, Kizilkaya $M$, Altoparlak U, Parlak M. Yoğun bakim hastalarinda görülen nozokomiyal uriner sistem enfeksiyonlari [Nosocomial urinary tract infections in the intensive care unit patients]. Mikrobiyol Bul. 2007;41:39-49.

26. Leone M, Albanèse J, Garnier F, Sapin C, Barrau K, Bimar MC, Martin C. Risk factors of nosocomial catheter-associated urinary tract infection in a polyvalent intensive care unit. Intensive Care Med. 2003;29:929-32.

27. Rosenthal VD, Maki DG, Salomao R, Moreno CA, Mehta Y, Higuera F, Cuellar LE, Arikan OA, Abouqal R, Leblebicioglu $\mathrm{H}_{\text {; }}$ International Nosocomial Infection Control Consortium. Device-associated nosocomial infections in 55 intensive care units of 8 developing countries. Ann Intern Med. 2006;145:582-91.

28. Çelik I, Demirdağ K, Denk A, Akbulut A, Kılıç SS. Nosocomial infections surveillance in the Surgical and Neurological Intensive Care Units of Firat Medical Center in year 2003. Klimik Derg. 2006;19:43-5.

29. Göktaş U, Yaman G, Karahocagil M, Bilici A, Katı İ, Berktaş M, Akdeniz H. Evaluation of nosocomial infections and antibiotic resistance profiles in the anesthesiology intensive care unit. J Turk Soc Intens Care. 2010;8:13-7. 